serenity. As I have already written and must write again, he was a true natural philosopher, of a kind, I think, more common in the last century than this, to whom curiosity about Nature on the broadest scale was the overmastering motive. In the Newalls' home at Madingley Rise, Cambridge, one heard science talked about in a queenly way, as an intrinsic part of the good life, in partnership with art and music. Sooner or later one met at the Newalls' everyone who counted in astrophysics and the allied parts of physics, and a dinner there was a true meeting of minds, where thoughts could be exchanged on a new phenomenon, a new flower, some development in farming, a Stonehenge discovery or a new star. Newall was the friend of Huggins, Michelson and Hale, and in his knowledge of optical design not their inferior. He was the friend, too, of many younger workers in astrophysics, who received from him hospitality, a captivating welcome and much sound sense as to the directions their energies should take. Withal he was a conservative, loth to embrace modern theories, seeing Nature rather as a complicated spectacle of phenomena than as a stamping-ground for principles. He belonged to the disappearing school which thought that insight into the phenomena apparent in the stars could be gained by consideration of simple laboratory experiments.

Newall was the most modest of men, never referring to his own achievements. Although generally unreserved in his conversation, he clung to reticence about deeper things as to the dress of decency. $\mathrm{He}$ was generous in praise of others, and generous and self-sacrificing in all matters of personal conduct. How he would have hated the thought of this bis obituary being written! His distinguished personal appearance was the index of a true distinction of mind. We shall long mourn one of the fathers of astrophysies in Great Britain.

E. A. Minne.

\section{Dr. J. McKeen Cattell}

Dr. J. McKeen Catrell, for the past fifty years editor of Science, the weekly journal of the American Association for the Advancement of Science, died in January, aged eighty-three, at Lancaster, Pennsylvania. He was long known as the "dean of American science", although his own subject strictly was psychology. In concurrently editing various periodicals his industry was immense ; but he won renown no less as teacher, research worker, and compiler of scientific reference books.

Son of the president of Lafayette College, also in Pennsylvania, Cattell after taking his degree there in 1880 went to study in Göttingen, Leipzig, Paris and Geneva, then returned to Leipzig to gain his Ph.D. in 1886. Two years thereafter he was lecturing in Cambridge, during which time he married Miss Josephine Owen, of London. Psychology as a separate study was in those days in its early development in the United States under Prof. William James of Harvard, and when Dr. Cattell received a call from Philadelphia, to fill a similar chair in the University of Pennsylvania, he went home to his career. In 1891 he proceeded to Columbia University, New York, where for twenty-six years he taught both pupils and teachers, engaging at the same time in researches upon measurement of behaviour, individual and group differences, measurement of psychophysical time, intensity and extensity, perception, fatigue, memory, and association of ideas.

Within about ten years after assuming the editor- ship of Science, Cattell began to edit also The American Naturalist, devoted to the biological sciences, and compiled the first edition of his "American Men of Science", a "Who's Who" of research workers. (This book, now grown to 28,000 names, unfortunately and surprisingly lacks a subject-index, and the same is true of its companion volume, "Leaders in Education", first published in 1932.)

Cattell was always a man who pertinaciously stuck to causes or views which he believed in, regardless of what might happen to himself therefrom. In October 1917, six months after the United States had entered the War of 1914-18, he wrote to various members of Congress "not to require drafted men to fight in Europe against their will". For this he was dismissed from his professorship at Columbia. Was such dismissal, when the United States was at war, a violation of academic freedom ? Eminent colleagues of Cattell's, Prof. John Dewey the philosopher, and Profs. James Harvey Robinson and Charles A. Beard the historians, protested furiously, and Prof. Beard resigned. Cattell later explained that he meant his letter to apply to conscientious objectors only; but he was not reinstated. Having been a member of the staff for a quarter of a century, Cattell then applied for his pension. It was refused him. Whereupon he sued the University for 150,000 dollars. The case was settled out of court by the award to Cattell of 45,000 dollars.

But by this time Cattell was so deeply occupied in editing his various publications that the loss of his post made little difference to him except to give him several additional hours per week to edit still others. Even while the last War was being fought out he began, from an office in the high tower of Grand Central Terminal, New York, to edit School and Society, which in the twenty-five years of his direction grew to be perhaps the leading educational journal in America. Longer still-forty years-was his tenure of the editorial chair of The Scientific Monthly, and during a critical period he presided also over Popular Science Monthly. In these multitudinous activities two of Cattell's four sons ably assisted him, and survive to carry on a considerable proportion of his work.

If, as some have said, there is in the United States no such thing as a school-leaving age, the gospel of unlimited educational opportunity owes much to the preaching of it by Cattell. But, completely enveloped in science as he was, he tended to attribute to it all the blessings of America and none of the difficulties. "The industrial applications of science," he said in one of his prefaces, "have quadrupled the productivity of labour, abolished slavery, the subjection of women, and child labour, and have made possible universal education even to the age of 18 or $20 . "$

In his long career Cattell was chosen president of many learned societies, including the American Association for the Advancement of Science, nor did his stand in the War of 1914-18 deter the French from electing him a Commander of the Legion of Honour. Willard Connely.

WE regret to announce the following deaths :

Prof. Karl Schuchhardt, formerly director of the Prehistoric Department of the Folk-Lore Museum in Berlin, aged eighty-four.

Dr. C. H. Townsend, director during 1902-37 of the New York Aquarium, on January 28, aged eightyfour. 